\title{
Model Persamaan Struktural untuk Mengkaji Kesan Pengurusan Rantaian Pembekalan Hijau dalam Industri Pembuatan
}

\author{
Wan Hasrulnizzam Wan Mahmood ${ }^{a, b^{*}}$, Mohd Nizam Ab Rahman $^{a}$, Baba Md Deros $^{\mathrm{a}}$ \\ ${ }^{a}$ Fakulti Kejuruteraan dan Alam Bina, Universiti Kebangsaan Malaysia, Malaysia \\ ${ }^{b}$ Fakulti Kejuruteraan Pembuatan, Universiti Teknikal Malaysia Melaka, Malaysia \\ *Corresponding author: hasrulnizzam@utem.edu.my
}

\section{Article history}

Received : 15 Mac 2012

Received in revised form :2 July

2012

Accepted :13 August 2012

Graphical abstract

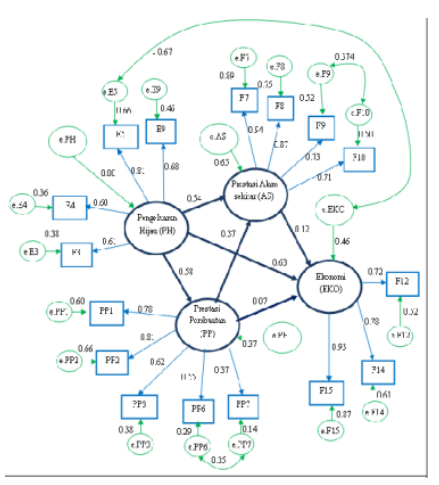

\section{Abstract}

Environmental issues such as pollution and the use of unrecyclable material are considered the global crises. As a result, green supply chain management (GSCM) was introduced as an alternative to the traditional approach of supply chain management (SCM) for environmental sustainability. This paper examines the impact of GSCM practices on the performance of: manufacturing, environment and economy by structural equation modelling. A total of 104 respondents were randomly selected from MS ISO 14001 manufacturing certified companies' represent 43.15 percent of the population. . The variables and the relationships between variables in the structural equation model are determined via interview with 24 representatives from various companies. The structural equation modelling analysis confirmed that there is a positive correlation between the variables especially greening production and manufacturing performance, environmental performance, and economic performance; while manufacturing performance has significant influence on the environmental performance.

Keywords: Green supply chain management; structural equation modelling; manufacturing industry in Malaysia

\begin{abstract}
Abstrak
Isu alam sekitar seperti pencemaran dan penggunaan sumber yang tidak boleh dikitar semula menjadi permasalahan global. Justeru, pengurusan rantaian pembekalan hijau (GSCM) diperkenalkan sebagai alternatif kepada pendekatan tradisional pengurusan rantaian pembekalan (SCM) untuk melestarikan kepentingan alam sekitar. Kajian mengkaji kesan pengamalan GSCM ke atas prestasi: pembuatan, alam sekitar dan ekonomi melalui reka bentuk dan pengesahan model persamaan struktural. Seramai 104 responden dipilih secara rawak mewakili 43.15 peratus bilangan populasi syarikat pembuatan yang mendapat pengiktirafan MS ISO 14001. Ciri - ciri pemboleh ubah dan hubungan antara pemboleh ubah dalam model persamaan struktural ditentukan melalui temu bual dengan 24 wakil pengurusan di pelbagai syarikat. Analisis model persamaan struktural menunjukkan terdapat perhubungan yang signifikan di antara pemboleh ubah di mana elemen GSCM iaitu pengeluaran hijau dapat memberikan impak kepada prestasi pembuatan, prestasi alam sekitar dan prestasi ekonomi, termasuk prestasi pembuatan menunjukkan pengaruh signifikan terhadap prestasi alam sekitar.
\end{abstract}

Kata kunci: Pengurusan rantaian pembekalan hijau; permodelan persamaan struktural; industri pembuatan di Malaysia

\subsection{PENGENALAN}

Bagi merealisasikan pembangunan mampan yang mesra alam tanpa menjejaskan pembangunan ekonomi, isu terpenting di abad ke-21 ini termasuklah penggunaan sumber alam secara terkawal yang dapat meminimumkan pengaruh ke atas alam sekitar [1]. Justeru, aplikasi teknologi hijau ditingkatkan terutamanya sektor industri pembuatan yang dikenal pasti sebagai penyumbang utama terhadap kesejahteraan alam sekitar [2]. Teknologi hijau merujuk kepada pembangunan dan aplikasi produk, peralatan serta sistem dan sumber semula jadi, dan meminimumkan atau mengurangkan kesan negatif daripada aktiviti manusia [3]. Ia mempunyai strategik yang lebih jauh daripada setakat mencapai autonomi tenaga dan menangani perubahan cuaca malah sebagai pencetus kepada perkembangan ekonomi negara.

Di Malaysia, Dasar Teknologi Hijau Negara dibangunkan dengan kerjasama semua pihak yang berkepentingan daripada setiap lapisan masyarakat mensasarkan pencapaian jangka panjang untuk negara dalam suasana yang mesra perniagaan [3]. Tidak kurang daripada itu, pihak kerajaan telah memperuntukkan geran penyelidikan dan pembangunan teknologi dan inovasi pengurusan alam sekitar. Skim kewangan teknologi hijau turut diperuntukkan sebanyak RM 1.5 bilion untuk menggalakkan aplikasi teknologi hijau di peringkat industri bagi tempoh Rancangan Malaysia ke sepuluh [1]. 
Menurut Hodges [4], setiap organisasi perlu mengadaptasi pendekatan teknologi hijau dalam amalan pengurusan yang menjadi kriteria utama pelanggan kini dan kehendak peraturan alam sekitar global selain daripada melaksanakan tanggungjawab sosial bersama-sama dengan rakan niaga atau pembekal. Malah, pembangunan teknologi hijau ini dilihat sebagai isu terpenting pada masa hadapan [5]. Pelbagai pendekatan telah diguna bagi meningkatkan kecekapan teknologi hijau. Kertas kerja ini memfokuskan kepada sistem pengurusan pembekalan hijau ( green supply chain management) atau GSCM yang dipercayai sebagai salah satu pendekatan penting dalam menjana kejayaan aplikasi teknologi hijau [6-7]. Rao [8] mendapati GSCM adalah inovatif dalam sistem pengurusan pembekalan tradisional (supply chain management) atau SCM yang mengutamakan prestasi operasi dan alam sekitar ekoran daripada kejayaan dalam sistem pengurusan alam sekitar (EMS) menerusi pensijilan ISO 14001. Di samping itu, peningkatan dalam peraturan alam sekitar [9-10] mendesak organisasi untuk menyertai GSCM dan meningkatkan persaingan dari segi pembuatan produk, pengurusan inventori, pembekal, pelanggan, dan infrastruktur dalam sistem pengurusan rantaian pembekalan peringkat global [11].

Evolusi ini menunjukkan GSCM semakin diiktiraf dan menjadi pilihan utama setiap pelanggan di peringkat global [12] yang merujuk kepada penambahbaikan berterusan dalam aspek alam sekitar, sistem sosial dan prestasi operasi pembuatan ataupun perkhidmatan hijau. Tambahan lagi, prestasi alam sekitar ini dijadikan sebagai ukuran asas dalam aktiviti pengurusan rantaian pembekalan [13]. Zhu dan Sarkis [14] mendapati bahawa GSCM adalah strategi utama kepada syarikat - syarikat elektronik seperti Dell, HP, IBM, Motorola, Sony, Panasonic, NEC, Fujitsu, dan Toshiba. Selain itu, terdapat syarikat-syarikat lain turut serta dalam menjalankan penyelidikan dan pembangunan (R\&D) produk hijau, dan mengenal pasti piawaian khas terhadap penggunaan bahan yang boleh memberikan kesan negatif kepada alam sekitar untuk pembekal mereka. Fenomena ini dianggap positif kerana selain daripada mewujudkan kesedaran terhadap kepentingan alam sekitar, GSCM dapat memberikan kelebihan untuk bersaing [15].

Kertas kerja ini merupakan hasil kajian yang dijalankan mengkaji kesan pengamalan GSCM dalam industri pembuatan di Malaysia melalui reka bentuk dan pengesahan model persamaan struktural. Sub topik berikutnya membincangkan kaedah kajian, diikuti dengan perbincangan lanjut pembangunan model GSCM berasaskan kepada permodelan persamaan struktural dan diakhiri dengan kesimpulan serta beberapa cadangan kajian untuk masa hadapan.

\subsection{KAEDAH KAJIAN}

Kajian soal selidik pos dan soal selidik temu bual digunakan sebagai kaedah pengumpulan data utama. Kajian soal selidik bertujuan untuk mendapatkan pandangan umum terhadap status pelaksanaan aplikasi teknologi hijau dalam pengurusan rantaian pembekalan (GSCM) di Malaysia. Berdasarkan kepada beberapa kajian terdahulu, kajian soal selidik merupakan penyumbang utama kepada dapatan kajian GSCM seperti Cheng et al. [6], Holt dan Ghobadian [16], Simpson et al. [17], dan Testa dan Iraldo [18] kerana kosnya yang rendah serta mengurangkan prasangka jawapan akibat pengaruh penemubual malah, ia merupakan kaedah yang paling ekonomi dalam kaedah pengumpulan data bagi kumpulan yang bersaiz besar [19]. Walizer dan Wienir [20] menyatakan soal selidik adalah bebas kepada pengkaji untuk mengenal pasti sesuatu masalah atau sebagainya secara sistematik dan konsisten. Menerusi soal selidik pengkaji boleh mempelbagaikan komponen pemboleh ubah untuk tujuan analisis [21].

Syarikat-syarikat pembuatan yang diiktiraf MS ISO 14001 telah dipilih sebagai populasi kajian. Pemilihan syarikat yang mempunyai EMS ini adalah pilihan tepat [22-24] kerana mereka sangat cenderung kepada GSCM. Malah, syarikat yang diiktiraf oleh satu badan pengiktirafan (seperti SIRIM) dapat memberikan kesimpulan yang baik kepada dapatan kajian [18] kerana responden mempunyai hala tuju yang seimbang malah mengamalkan peraturan yang diperakui oleh agensi yang sama. Sehubungan dengan itu, Hu dan Hsu [25] membuktikan bahawa kesimpulan kajian yang dibuat dapat membantu agensi terbabit untuk menambahbaik sistem pelaksanaan di kalangan ahli kumpulan. Tambahan lagi, kadar respons dapat ditingkatkan dengan kerjasama agensi dalam kaedah pengumpulan data [26].

Bilangan syarikat yang diiktiraf MS ISO 14001 sehingga tahun 2009 adalah 522 syarikat [27]. Penulis mempertimbangkan tempoh pengiktirafan pensijilan MS ISO 14001 sekurang kurangnya dua tahun seperti yang dicadangkan oleh Rao [24] untuk dipilih sebagai responden kerana tempoh tersebut adalah tempoh matang kepada organisasi menjalankan EMS. Walaupun demikian, jumlah tersebut melibatkan bilangan syarikat bukan pembuatan yang terdiri daripada syarikat pembinaan, perkhidmatan, produk minyak dan gas, dan perladangan sebanyak 215 syarikat. Tambahan lagi, terdapat 66 buah syarikat pembuatan yang diiktiraf MS ISO 14001 mempunyai syarikat pembuatan bersama (syarikat cawangan). Oleh yang demikian, hanya 241 syarikat pembuatan yang diiktiraf MS ISO 14001 dipilih sebagai populasi kajian. Namun begitu, hanya 94 set jawapan lengkap yang diperolehi menerusi soal selidik pos sementara 12 set soalan lagi didapati dalam sesi temu bual bersama responden. Oleh itu, analisis kajian ini adalah mewakili bilangan populasi kajian sebanyak 43.15 peratus.

Berdasarkan kepada kajian GSCM terdahulu, kadar respons dalam kajian ini adalah lebih baik berbanding dengan kajian oleh Bowen [27], Holt dan Ghobadian [16], Naini et al. [23], Olugu et al. [29], dan Hu dan Hsu [25]. Sehubungan dengan itu, kajian oleh Rao [24], dan Rao dan Holt [30] hanya melibatkan sejumlah 52 responden dalam pembentukan model GSCM ke atas syarikat pembuatan di Asia Tenggara. Kajian Simpson et al. [17] di Australia pula melibatkan sebanyak 55 responden, iaitu bersamaan dengan 13.75 peratus bilangan populasi. Dengan kata lain, kadar respons kajian ini adalah sesuai untuk mewakili konteks Malaysia malah saiz sampel iaitu 104 dapat digunakan untuk pembentukan model persamaan struktural [31] dan lain-lain analisis statistik [32] bagi menunjukkan impak GSCM secara lebih jelas.

\subsection{PEMBANGUNAN MODEL PERSAMAAN} STRUKTURAL

Model persamaan struktural (Structural Equation Model-SEM) merupakan kaedah analisis bagi data kuantitatif yang merupakan gabungan dan integrasi analisis faktor dan analisis rangkaian [31]. Analisis faktor mengenal pasti sama ada item-item soal selidik mengukur konsep (pemboleh ubah) yang sama, iaitu mengenal pasti sama ada pemboleh ubah pendam (latent variable) diwakili oleh pemboleh ubah-pemboleh ubah indikatornya, manakala analisis rangkaian mengenal pasti perhubungan antara pemboleh ubah-pemboleh ubah dalam perhubungan sebab-akibat dalam suatu model regresi. Model persamaan struktural boleh dibentuk daripada gabungan beberapa model pengukuran, yang dibentuk berdasarkan teori [33].

Jadual 1 menunjukkan ringkasan model pengukuran yang digunakan dalam kajian terdahulu. Berdasarkan kepada Jadual 1, 
didapati bahawa daripada 13 kajian terdahulu, 12 penyelidik telah memilih elemen GSCM dalaman sebagai model pengukuran utama dalam pembentukan model persamaan struktural. Rao [25, 34] membuktikan bahawa pemboleh ubah ini merupakan pemboleh ubah utama dalam pelaksanaan GSCM kerana pengaruh elemen dalaman melebihi elemen luaran. Malah, elemen GSCM dalaman dapat memberikan organisasi pembuatan lebih kompetensi [35-37], peningkatan prestasi ekonomi atau kewangan [38-39], dan prestasi hijau atau alam sekitar [30, 40]. Selari dengan kajian Zhu et al. [41] yang membuktikan bahawa keputusan positif yang dinikmati menerusi elemen GSCM dalaman dapat memberikan motivasi kepada syarikat pembuatan lain. Ini kerana, elemen dalaman ini dapat meningkatkan kecekapan operasi syarikat dengan pengurangan kos tersembunyi (hidden cost) dan penambahbaikan persekitaran kerja yang lebih sihat [42]. Walaupun begitu, elemen GSCM dalaman bagi setiap kajian adalah berbeza dan ia adalah tertakluk kepada keputusan ujian pengesahan elemen menerusi analisis faktor [30].

Jadual 1 Ringkasan model pengukuran dalam pembentukan model persamaan struktural kajian terdahulu

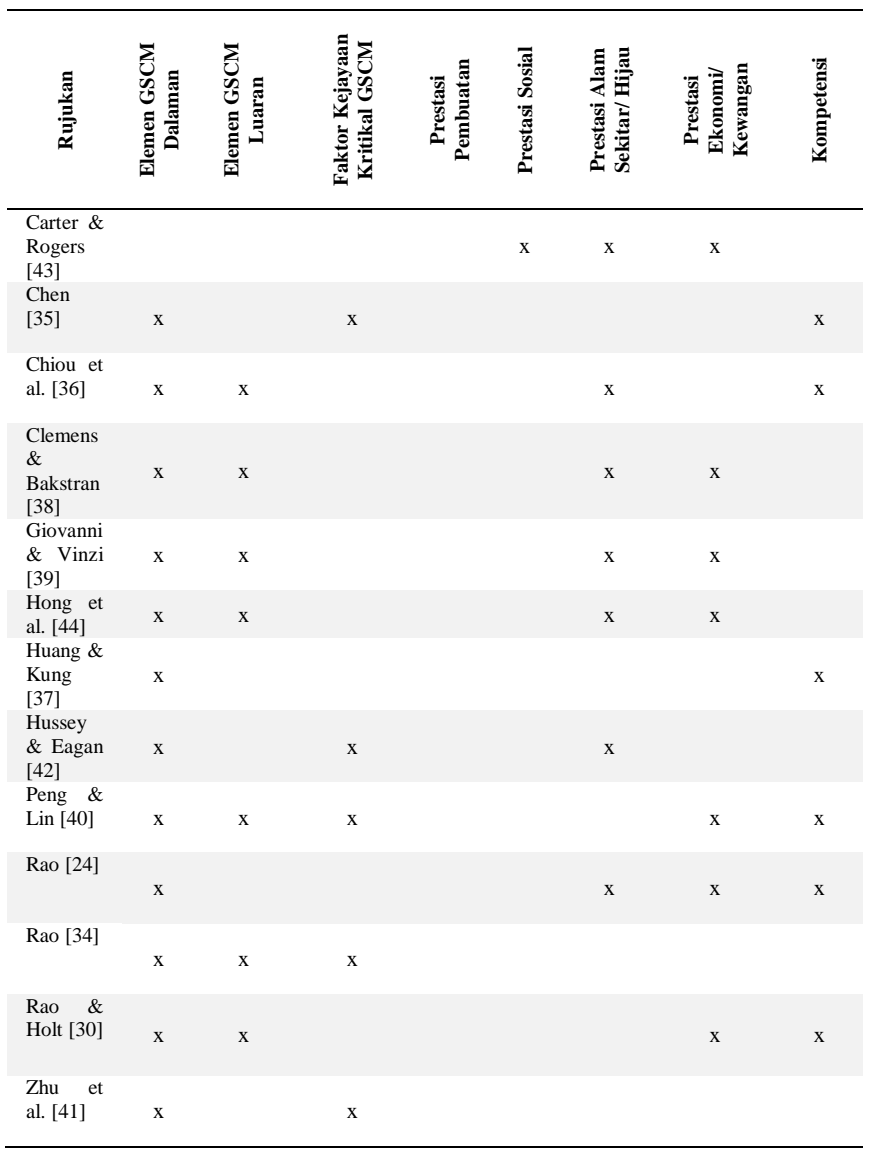

Jadual 1 turut menunjukkan bahawa elemen GSCM dalaman dan luaran serta faktor kejayaan kritikal GSCM merupakan pemboleh ubah tidak bersandar sementara prestasi alam sekitar/ hijau, prestasi ekonomi/ kewangan, kompentensi dijadikan sebagai pemboleh ubah bersandar dalam model persamaan struktural. Pemboleh ubah tidak bersandar dipilih sebagai elemen yang mempengaruhi pemboleh ubah bersandar. Malah, setiap pemboleh ubah boleh dipilih sebagai kedua-dua jenis pemboleh ubah bersandar atau tidak bersandar [43]. Rao [24, 34], dan Zhu et al. [41] menegaskan bahawa pemilihan pemboleh ubah mestilah ini mengambil kira tujuan kajian dan aplikasinya ke atas ciri-ciri fokus bagi organisasi.

Selain itu, didapati bahawa pengkaji terdahulu tidak menggunakan prestasi pembuatan sebagai model pengukuran dalam pembentukan model SEM walaupun kajian seperti Beamon [45] dan Olugu [29] membuktikan bahawa prestasi pembuatan merupakan faktor utama yang perlu diambil kira dalam pelaksanaan GSCM. Tambahan lagi, bagi syarikat pembuatan kecil dan sederhana, prestasi pembuatan menjadi fokus utama dalam operasi pengeluaran berbanding dengan penyelesaian kepada permasalahan alam sekitar [42]. Ekoran daripada itu, penulis telah memilih prestasi pembuatan sebagai salah satu model pengukuran selain daripada elemen GSCM dalaman, prestasi alam sekitar dan faedah ekonomi/ kewangan. Pemilihan model - model pengukuran tersebut dibuat berasaskan kepada keputusan analisis faktor manakala tujuan pembentukan model persamaan struktural dibuat untuk menjelaskan secara menyeluruh hubungan antara pemboleh ubah yang telah dipilih dalam kajian ini.

Dengan menggunakan perisian AMOS 5.0, petunjuk SEM, iaitu ujian CMIN (the likelihood ratio Chi Square), garis dasar (baseline) iaitu NFI (normed fit index), RFI (relative fit index), IFI (incremental fit index), TLI (Tucker-Lewis index), dan CFI (comparative fit index), RMSEA (Root Mean Square Error of Approxiamation) dan lain- lain dapat mengenal pasti corak varians dan kovarians pada data kajian. Ia juga dipilih untuk memastikan kebolehpercayaan dan kesepadanan model persamaan struktural terhadap dapatan kajian. Dengan ini, hanya model yang signifikan dan kurang mempunyai ralat dengan data kajian diterima.

\subsection{Model Pengukuran}

Model pengukuran dibentuk oleh perhubungan pemboleh ubah pendam, pemboleh ubah indikator dan ralat varians [33]. Pemboleh ubah pendam merupakan pemboleh ubah yang tidak diukur secara terus daripada kajian di mana diwakili oleh pemboleh ubah indikator. Pemboleh ubah indikator merupakan pemboleh ubah yang diukur dengan menggunakan ralat kajian dan ia turut dikenali juga sebagai pemboleh ubah yang diperhatikan (observed variable). Data yang diukur terus daripada responden kajian merupakan pemboleh ubah indikator di mana diletakkan dalam petak segi empat dan dua anak panah menghala kepadanya dalam model persamaan struktural. Sementara itu, pemboleh ubah tidak diperhatikan (unobserved variable) diletakkan dalam bulatan. Selain itu, model pengukuran melibatkan pemboleh ubah bersandar yang ditujui oleh anak panah sehala dan pemboleh ubah bebas yang diandaikan tidak mempunyai ralat diwakili oleh anak panah sehala yang menghala keluar.

Terdapat empat kumpulan pemboleh ubah dibangunkan dalam kajian soal selidik iaitu prestasi pembuatan, elemen GSCM, faedah GSCM dan faktor kejayaan kritikal GSCM. Walaupun begitu, elemen GSCM dikonstruk semula kepada tiga kumpulan elemen GSCM iaitu pengeluaran hijau, penerapan hijau luaran dan pengoptimuman sumber di mana elemen pengeluaran hijau merupakan elemen GSCM dalaman sementara bakinya adalah elemen GSCM luaran. Dalam pada itu, faedah GSCM dibahagikan kepada dua konstruk baharu iaitu faedah prestasi ekonomi dan prestasi alam sekitar, sementara faktor kejayaan kritikal GSCM terdiri daripada dua kumpulan konstruk baharu iaitu faktor komitmen dan pematuhan. Berdasarkan kepada pekali korelasi, didapati bahawa kesemua konstruk baru yang dibentuk adalah bebas antara satu sama lain. Kajian oleh Rao [24, 34] membuktikan bahawa ciri-ciri konstruk tersebut boleh dijadikan model pengukuran dalam pembentukan model persamaan struktural GSCM di mana kumpulan item asal dalam soal selidik 
boleh diabaikan. Dengan erti kata lain, konstruk - konstruk tersebut boleh mewakili kumpulan item soal selidik yang lebih homogen [32-33].

Kajian oleh Hussey dan Eagan [42] menegaskan bahawa pemilihan pemboleh ubah indikator mesti relevan dengan objektif kajian, namun, Rao [24, 34] membuktikan bahawa tidak semua pemboleh ubah indikator dapat digunakan dalam model pengukuran. Di samping itu, Chiou et al. [36] mendapati bahawa pemboleh ubah indikator ini terdiri daripada dua jenis iaitu pemboleh ubah objektif dan pemboleh ubah subjektif. Pemboleh ubah objektif ini merupakan pemboleh ubah yang boleh diukur secara langsung manakala pemboleh ubah subjektif merupakan pemboleh ubah bersandar di mana boleh diukur pada tempoh tertentu. Sehubungan dengan itu, penetapan pemboleh ubah indikator boleh dilakukan menerusi perbincangan bersama dengan responden kajian bagi mengesahkan hubungan antara pemboleh ubah [39].

Penulis memilih untuk melakukan temu bual susulan (followup interviews) terhadap 24 syarikat pembuatan yang turut merupakan responden dalam kajian soal selidik untuk mengenal pasti pemboleh ubah indikator yang relevan dengan kajian ini. Temu bual tersebut dijalankan melalui telefon sementara e-mel digunakan sebagai medium penghantaran dokumen kepada responden seperti mana kajian oleh Simpson et al. [17], dan Zhu et al. [41]. Temu bual ini merupakan temu bual tidak berstruktur bertujuan untuk mengesahkan pemboleh ubah indikator dalam pembangunan model persamaan struktural.

Keputusan temubual merumuskan pemboleh ubah indikator bagi prestasi pembuatan (PP) adalah masa dalam proses pembuatan (PP1), masa pengeluaran (PP2), kerja-dalam-proses (PP3), kos pembuatan (PP4), penggunaan mesin/ peralatan (PP6), dan fleksibiliti (PP7), diikuti dengan pemboleh ubah indikator pengeluaran hijau (PH) yang diwakili oleh penjimatan guna tenaga, air, dan bahan buangan (E9), menggunakan pendekatan hijau sebagai kriteria utama dalam proses pembuatan (E3), mengoptimumkan proses pengurangan sisa pepejal (E5), dan pertimbangan dalam reka bentuk (E4). Di samping itu, faedah prestasi alam sekitar (AS) melibatkan pemboleh ubah indikator yang terdiri daripada pematuhan undang-undang alam sekitar, F10, pengurangan penghasilan sisa buangan (F7), kitar semula (F9), dan pengurangan pencemaran (F8), sementara faedah ekonomi (EKO) dinilai menerusi pemboleh ubah indikator pasaran saham (F15), keuntungan marginal (F12) dan jualan (F14).

Sebanyak 14 item soal selidik disingkirkan dalam pembentukan model persamaan struktural GSCM di mana dua daripada jumlah tersebut merupakan item prestasi pembuatan iaitu kualiti produk (PP5), dan kos pembuatan, (PP4), diikuti oleh tiga item dalam pengeluaran hijau iaitu penggunaan bahan mentah mesra alam (E1), menggantikan bahan mentah yang meragukan (E2), dan menggunakan bahan kitar semula dalaman (E10), tiga item dalam faedah prestasi alam sekitar iaitu, penjimatan kos (F5), peningkatan imej (F6), dan tanggunjawab sosial (F13), sementara keseluruhan item faktor kejayaan kritikal GSCM disingkirkan. Penyingkiran ini dibuat berasaskan kepada dua faktor iaitu; pertama - mempunyai konsep yang bertindih dengan beberapa konstruk pemboleh ubah yang dikenal pasti menerusi analisis faktor pengesahan; kedua - keputusan yang dicapai bersama wakil industri yang mendapati faktor kejayaan kritikal GSCM adalah sangat subjektif untuk disepadankan dengan model SEM. Oleh itu, ia tidak dibincangkan dalam kertas kerja ini.

\subsection{Analisis Faktor Pengesahan}

Model persamaan struktural diuji bagi mengenal pasti kebolehpercayaan model pengukuran yang dipilih [33] di mana ujian statistik seperti CMIN, NFI, RFI, IFI, TLI, CFI dan RMSEA dianalisis kerana sekiranya item pengukuran (data kajian) tidak sepadan dengan pemboleh ubah pendamnya dalam model pengukuran, model persamaan struktural mempunyai kebolehpercayaan yang rendah. Terdapat dua model dibangunkan iaitu model cadangan dan model modifikasi. Disebabkan model modifikasi lebih sepadan dengan data kajian, maka, model cadangan tidak dibincangkan. Giovanni dan Vinzi [39] membuktikan bahawa cadangan ke atas model modifikasi boleh diterima kerana simulasi menggunakan komputer merangkumi analisis data kajian secara saintifik. Namun begitu, Zhu et al. [41] membuktikan bahawa pengkaji boleh mengabaikan cadangan modifikasi tersebut sekiranya analisis faktor pengesahan yang dijalankan ke atas model cadangan (asal) mempunyai kebolehpercayaan yang tinggi bagi kesepadanan data kajian.

Jadual 2 menunjukkan keputusan regresi, ralat piawai dan nisbah kritikal bagi model modifikasi seperti mana yang ditunjukkan pada Rajah 1. Berdasarkan kepada Jadual 2, didapati bahawa ralat piawai bagi pemboleh ubah kajian dalam model modifikasi adalah kecil kecuali PP1 dengan nilai ralat piawai iaitu, 0.695. Ini kerana, semakin kecil nilai ralat piawai, semakin besar keupayaan pemboleh ubah tidak bersandar untuk meramal pemboleh ubah bersandar [33]. Keputusan analisis faktor pengesahan itu turut menunjukkan nilai nisbah kritikal bagi hubungan pemboleh ubah pendam pengeluaran hijau dengan prestasi pembuatan, prestasi alam sekitar dan prestasi ekonomi adalah signifikan pada aras 0.05 .

Nisbah kritikal bagi PH dan AS lebih utama, iaitu sebanyak 4.015 diikuti oleh perhubungan antara $\mathrm{PH}$ dan $\mathrm{PP}$, dan $\mathrm{PH}$ dan EKO dengan nilai nisbah kritikal masing-masing iaitu 2.893 dan 2.662. Model SEM juga menunjukkan hubungan PP dan AS adalah signifikan untuk menyatakan bahawa prestasi pembuatan dapat memberikan impak terhadap prestasi alam sekitar. Sementara itu, hubungan EKO dengan PP dan AS didapati tidak signifikan. Ini menunjukkan dapatan kajian tidak dapat membuktikan pengaruh prestasi pembuatan dan alam sekitar terhadap peningkatan prestasi ekonomi seperti kajian oleh Rao [24].

Keseluruhan pemboleh ubah indikator adalah signifikan pada aras 0.05 di mana keputusan tersebut mengesahkan bahawa pemboleh ubah pendam yang dibentuk dipengaruhi oleh pemboleh ubah indikator yang dipilih [32]. Perhubungan dua hala antara tiga pasangan pemboleh ubah yang dimodifikasi adalah signifikan. Ini bermaksud bahawa terdapat silang hubungan antara pemboleh ubah pendam dan pemboleh ubah indikator antara satu sama lain seperti hubungan antara pemboleh ubah indikator E5, iaitu mengoptimumkan proses pengurangan sisa pepejal dan pemboleh ubah pendam prestasi ekonomi. Malah, wujud perhubungan yang signifikan antara pemboleh ubah indikator dalam pemboleh ubah pendam masing-masing seperti hubungan pemboleh ubah indikator iaitu penggunaan mesin/peralatan (PP6) dan fleksibiliti (PP7) dalam pemboleh ubah pendam prestasi pembuatan, hubungan pemboleh ubah indikator F9, iaitu kitar semula dan pemantuhan undang-undang alam sekitar, F10 dalam pemboleh ubah pendam prestasi amal sekitar. 
Jadual 2 Keputusan regresi, ralat piawai, nisbah kritikal bagi pemboleh ubah pendam dalam model modifikasi

\begin{tabular}{|c|c|c|c|c|c|c|}
\hline $\begin{array}{c}\text { Pembolehubah } \\
\text { bersandar }\end{array}$ & $\begin{array}{c}\text { Ikon } \\
\text { rangkaian }\end{array}$ & $\begin{array}{c}\text { Pembolehubah } \\
\text { tidak } \\
\text { bersandar }\end{array}$ & $\begin{array}{l}\text { Pekali } \\
\text { regresi }\end{array}$ & $\begin{array}{c}\text { Ralat } \\
\text { piawai }\end{array}$ & $\begin{array}{c}\text { Nisbah } \\
\text { Kritikal }\end{array}$ & $\stackrel{\text { Nilai }}{\text { P }}$ \\
\hline PP & $<---$ & $\mathrm{PH}$ & 0.310 & 0.107 & 2.893 & 0.004 \\
\hline AS & $<--$ & PH & 0.564 & 0.140 & 4.015 & $* * *$ \\
\hline AS & $<---$ & PP & 0.704 & 0.291 & 2.414 & 0.016 \\
\hline EKO & $<---$ & $\mathrm{PH}$ & 1.084 & 0.407 & 2.662 & 0.008 \\
\hline EKO & $<--$ & AS & 0.199 & 0.350 & 0.568 & 0.570 \\
\hline EKO & $<--$ & PP & -0.234 & 0.497 & -0.471 & 0.638 \\
\hline E9 & $<--$ & $\mathrm{PH}$ & 1.000 & & & \\
\hline E3 & $<--$ & $\mathrm{PH}$ & 0.820 & 0.144 & 5.687 & $* * *$ \\
\hline E5 & $<--$ & PH & 1.198 & 0.178 & 6.739 & $* * *$ \\
\hline E4 & $<--$ & $\mathrm{PH}$ & 0.777 & 0.140 & 5.543 & $* * *$ \\
\hline F15 & $<--$ & EKO & 1.000 & & & \\
\hline F12 & $<--$ & EKO & 0.801 & 0.096 & 8.314 & $* * *$ \\
\hline F14 & $<--$ & EKO & 0.713 & 0.077 & 9.253 & $* * *$ \\
\hline F10 & $<--$ & AS & 1.000 & & & \\
\hline F7 & $<--$ & AS & 1.312 & 0.148 & 8.840 & $* * *$ \\
\hline F9 & $<---$ & AS & 0.976 & 0.110 & 8.875 & $* * *$ \\
\hline F8 & $<--$ & AS & 1.248 & 0.150 & 8.317 & $* * *$ \\
\hline PP7 & $<---$ & PP & 1.000 & & & \\
\hline PP6 & $<-$ & PP & 1.739 & 0.463 & 3.759 & $* * *$ \\
\hline PP3 & $<-$ & PP & 1.366 & 0.421 & 3.242 & 0.001 \\
\hline PP2 & $<--$ & PP & 1.876 & 0.541 & 3.471 & $* * *$ \\
\hline PP1 & $<---$ & PP & 2.396 & 0.695 & 3.446 & $* * *$ \\
\hline E5 & $\langle--\rangle$ & EKO & -0.089 & 0.023 & -3.864 & $* * *$ \\
\hline F9 & $\langle-\rangle\rangle$ & F10 & 0.046 & 0.015 & 3.199 & 0.001 \\
\hline PP6 & $\langle--\rangle$ & PP7 & 0.083 & 0.026 & 3.123 & 0.002 \\
\hline
\end{tabular}

Nota: *** signifikan pada aras 0.05
Rajah 1 menunjukkan model modifikasi persamaan struktural GSCM yang merangkumi pekali korelasi setiap ikon rangkaian dan ikon kovarians. Nilai pekali korelasi piawai tinggi (dari 0.541 hingga 0.943) menunjukkan semua pemboleh ubah indikator secara signifikan dapat mewakili pemboleh ubah pendam kecuali PP7 yang mendapat pekali korelasi iaitu 0.37 pada aras rendah. Analisis menunjukkan sebanyak 0.628 atau 62.8 peratus varians dalam prestasi ekonomi, 0.579 atau 57.9 peratus varians dalam prestasi pembuatan, dan 0.542 atau 54.2 peratus varians dalam prestasi alam sekitar boleh diramal oleh pengeluaran hijau seperti yang ditunjukkan pada Rajah 1. Sementara 0.362 atau 36.2 peratus varians dalam prestasi alam sekitar boleh diramal menerusi prestasi pembuatan dalam model modifikasi persamaan struktural.

Dapatan kajian ini selari dengan kajian oleh Giovanni dan Vinzi [39], dan Rao [24] yang membuktikan bahawa terdapat hubungan yang signifikan antara elemen GSCM dalaman terhadap pretasi alam sekitar dan prestasi ekonomi. Malah, model kajian ini menyokong dapatan kajian oleh Peng dan Lin [40], dan Clemens dan Bakstran [38] yang membuktikan bahawa pengeluaran hijau mempunyai hubungan yang signifikan dengan prestasi ekonomi/ kewangan.

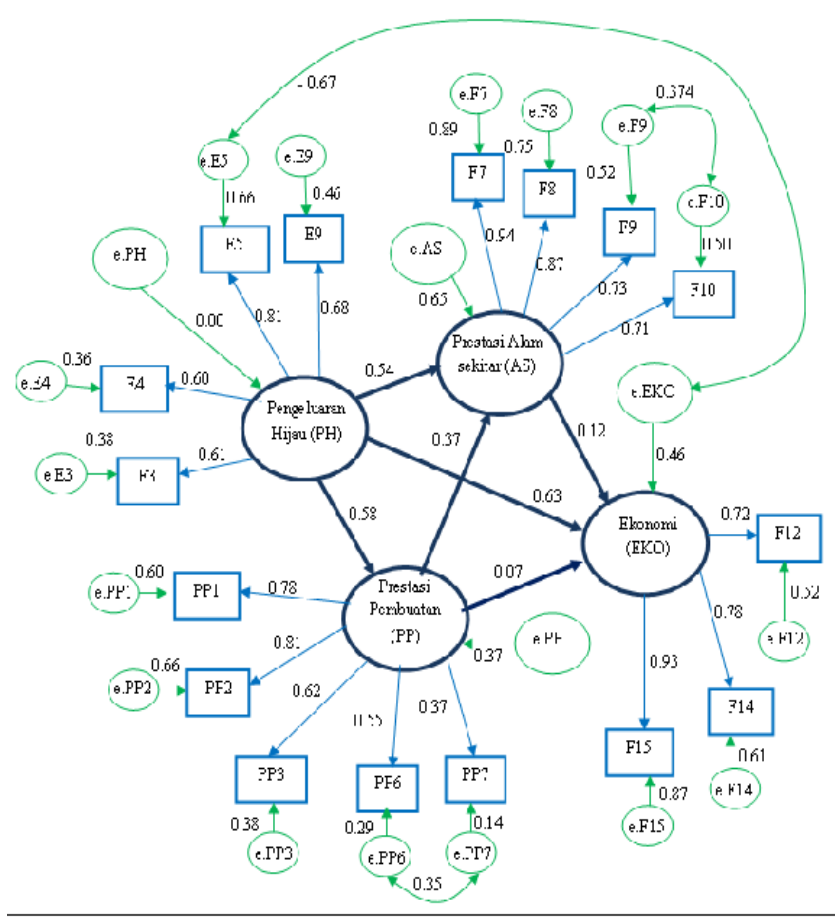

Rajah 1 Model persamaan struktural GSCM (Modifikasi)

$\mathrm{CMIN}=179.162$; darjah kebebasan $=95$; nilai $\mathrm{P}=0.000$; $\mathrm{NFI}=0.817 ; \mathrm{RFI}=0.768$;

$\mathrm{IFI}=0.905 ; \mathrm{TLI}=0.876 ; \mathrm{CFI}=0.902 ; \mathrm{RMSEA}=0.093$

\subsection{KESIMPULAN DAN CADANGAN KAJIAN AKAN} DATANG

Penulis merumuskan GSCM dapart memberikan impak yang signifikan terhadap tiga jenis prestasi termasuk prestasi pembuatan; prestasi alam sekitar; dan prestasi ekonomi, termasuk prestasi pembuatan yang turut memberikan pengaruh kepada peningkatan dalam prestasi ekonomi. Walaupun begitu, model persamaan struktural GSCM yang dibangunkan adalah bersifat menyeluruh kerana setiap item atau pemboleh ubah indikator 
dipilih berdasarkan kepada kajian ilmiah di mana tidak dibincangkan tentang aplikasinya.

Terdapat batasan kajian seperti tempoh kajian, kos, polisi dan kerahsiaan syarikat menjadikan skop kajian terpaksa dikecilkan bahkan model persamaan struktural GSCM tidak dapat diuji secara menyeluruh. Bagi tujuan penambahbaikan terhadap batasan kajian ini, beberapa cadangan kajian akan datang dipertimbangkan seperti berikut:

- Kajian susulan ke atas beberapa elemen tambahan yang boleh digunakan sebagai penambahbaikan model persamaan struktural GSCM terutamanya elemen GSCM luaran dan faktor kejayaan kritikal GSCM.

- Dengan menjadikan syarikat yang diiktiraf MS ISO 14001 sebagai penanda aras, model persamaan struktural GSCM tersebut boleh diuji kepada lain-lain sektor pembuatan termasuk industri perkhidmatan.

- Memilih syarikat industri kecil dan sederhana (IKS) sebagai responden kajian atau syarikat multinasional (MNC) atau kedua-duanya bagi pengukuhan model persamaan struktural GSCM. Syarikat IKS merupakan kelompok majoriti di Malaysia manakala syarikat MNC banyak melibatkan syarikat pemilikan asing. Dengan kata lain, penambahbaikan yang dapat dibuat terhadap syarikat IKS dapat memberikan impak kepada ekonomi Malaysia.

- Mengkaji pendekatan syarikat dalam aktiviti penambahbaikan berterusan seperti sistem pembuatan Lean, Six Sigma dan dan lain-lain dapat mempengaruhi GSCM di Malaysia.

Berdasarkan kepada beberapa cadangan kajian akan datang, penulis yakin bahawa aplikasi teknologi hijau yang merupakan hasrat negara dapat dilaksanakan dengan jayanya melalui pembuktian kepada syarikat - syarikat lain tentang kaedah dan faedah yang boleh dilaksanakan. Tambahan lagi, model persamaan struktural GSCM yang dibentuk dapat menjadikan rujukan dan hala tuju syarikat terutamanya dalam sektor pembuatan. Selain itu, aplikasi teknologi hijau dalam pengurusan rantaian pembekalan dapat ditingkatkan kepada elemen dalaman dan luaran ke arah pemuliharaan alam sekitar yang memberikan kesejahteraan sejagat.

\section{PENGHARGAAN}

Kajian ini adalah tajaan Universiti Kebangsaan Malaysia (UKM) melalui geran FRGS (UKM-KK-02-FRGS0202-2010) dan Kementerian Pengajian Tinggi terutamanya Universiti Teknikal Malaysia Melaka (UTeM) di bawah "Skim Latihan Akademik IPTA (SLAI)".

\section{Rujukan}

[1] DOE. 2011. http://www.doe.gov.my [14 September 2011]

[2] MIDA. 2011. www.mida.gov.my [14 September 2011].

[3] KeTTHA. 2009. Dasar Teknologi Hijau Negara. Malaysia.

[4] Hodges, C. P. 2005. A Facility Manager's Approach to Sustainability. Journal of Facilities Management. 3(4): 312-324.

[5] Baharum, M. R. \& Pitt, M. 2009. Determining a Conceptual Framework for Green FM Intellectual Capital. Journal of Facilities Management. 7(4): 267-282.

[6] Cheng, J. H., Yeh, C. H. \& Tu, C. W. 2008. Trust and Knowledge Sharing in Green Supply Chains. Supply Chain Management: An International Journal. 13/4: 283-295.

[7] Robinson, R. \& Wilcox, S. 2008. The Greening of Supply Chains. Supply Chain Management Review. 12(7): 61-66.
[8] Rao, P. 2007. Greening of Supply Chain: An Emperical Study for Smes in Philippine Context. Journal of Asia Business Studies. 55-66.

[9] Cetindamar, D. 2001. The Role of Regulations In The Diffusion of Environment Technologies: Micro and Macro Issues. European Journal of Innovation Management. 14(4): 186-193.

[10] Pilkington, A. \& Dyerson, R. 2006. Innovation in Distruptive Regulatory Environments: A Patent Study of Electric Vehicle Technology Development. European Journal of Innovation Management. 23(1): 7991.

[11] Manuj, I. \& Mentzer, J. T. 2008. Global Supply Chain Risk Management Strategies. International Journal of Physical Distribution and Logistics Management. 38(3): 192-223.

[12] Corbett, C. J. \& Klassen, R. D. 2006. Extending the Horizons: Environmental Excellence as Key to Improving Operations. Manufacturing \& Service Operations Management. 8(1): 5-22.

[13] Sarkis, J. 1995. Supply Chain Management and Environmentally Conscious Design \& Manufacturing. International Journal of Environmentally Conscious Design \& Manufacturing. 4(2): 43-52.

[14] Zhu, Q. \& Sarkis, J. 2006. An Inter-sectoral Comparison of Green Supply Chain Management in China: Drivers and Practices. Journal of Cleaner Production. 14(5): 472-486.

[15] Walton S. V., Handfield R. B. \& Melnyk, S. A. 1998. The Green Supply Chain: Integrating Suppliers into Environmental Management Process. International Journal of Purchasing and Materials Management. 34(2): $2-11$.

[16] Holt, D. \& Ghobadian, A. 2009. An Empirical Study of Green Supply Chain Management Practices Amongst UK Manufacturers. Journal of Manufacturing Technology Management. 20(7): 933-956.

[17] Simpson, D. Y., Power, D. J. \& Samson, D. 2007. Greening The Automotive Supply Chain: A Relationship Perspective. International Journal of Operations \& Production Management. 27(1): 28-48.

[18] Testa, F. \& Iraldo, F. 2010. Shodows and Lights Of GSCM (Green Supply Chain Management): Determinants and Effects of These Practices Based on a Multi-National Study. Journal of Cleaner Production. 18: 953-962.

[19] Nachmias, C. F. \& Nachmias, D. 1992. Research Methods in the Social Sciences. Edisi ke-4. New York: St Martin's Press.

[20] Walizer, M. H. \& Wienir, P. L. 1978. Research Methods and Analysis: Searching for Relationship. New York, USA: Harper \& Row Publishers.

[21] Babbie, E. 1990. Survey Research Methods. Belmont: Wadsworth.

[22] Eltayeb, T. K., Zailani, S. \& Ramayah, T. 2011. Green Supply Chain Initiatives Among Certified Companies in Malaysia and Environmental Sustainability: Investigating the Outcomes.Resources, Conservation and Recycling. 55(5): 495-506.

[23] Naini, S. G. J., Aliahmadi, A. R. \& Jafari-Eskandari, M. 2011. Designing a Mixed Performance Measurement System for Environmental Supply Chain Management Using Evolutionary Game Theory and Balanced Scorecard: A Case Study of an Auto Industry Supply Chain. Resources, Conservation and Recycling. 55(6): 593-603.

[24] Rao, P. 2002. Greening the Supply Chain: A New Initiative in South East Asia. International Journal of Operations \& Production Management. 22(6): 632-655.

[25] Hu, A. H. \& Hsu, C. W. 2006. Empirical Study in the Critical Factors of Green Supply Chain Management (GSCM) Practice in the Taiwanese Electrical and Electronics Industries. Proceeding of the IEEE International Conference on Management of Innovation and Technology. 853-857.

[26] Lee, S.-Y. 2008. Drivers for the Participation of Small and MediumSized Suppliers in Green Supply Chain Initiatives. Supply Chain Management: An International Journal 13(3): 185-198.

[27] SIRIM QAS. 2011. www.sirim-qas.com.my/ [5 Januari 2011].

[28] Bowen, F., Cousins, P., Lamming, R. \& Faruk, A. 2001. Horses for Courses: Explaining the Gap Between Theory and Practice Of Green Supply. Greener Management International. 35: 41-60.

[29] Olugu, E. U., Wong, K. Y. \& Shaharoun, A. M. 2011. Development of Key Performance Measures for the Automobile Green Supply Chain. Resources, Conservation and Recycling. 55(6): 567-579.

[30] Rao, P. \& Holt, D. 2005. Do Green Supply Chains Lead to Competitiveness and Economic Performance? International Journal of Operations \& Production Management. 25(9): 898-916.

[31] Kline, R. B. 1998. Principles and Practice of Structural Equation Modeling. NY: Guilford Press.

[32] Dunteman, G. H. 1984. Introduction to Multivariate Analysis. Thousand Oaks, CA: Sage Publications.

[33] Chua, Y.P. 2009. Statistik Penyelidikan Lanjutan II: Ujian Regresi, Analisi Faktor dan Analisis SEM. Buku 5. Kuala Lumpur: McGraw-Hill (Malaysia) Sdn Bhd. 
[34] Rao, P. 2004. Greening Production: A South-East Asian Experience. International Journal of Operations \& Production Management. 24(3): 289-320.

[35] Chen, Y-S. 2011. Green Organizational Identity: Sources and Consequence. Management Decision. 49 (3): 384-404.

[36] Chiou, T-Y., Chan, H. K., Lettice, F. \& Chung, S. H. 2011. The Influence of Greening the Suppliers and Green Innovation on Environmental Performance and Competitive Advantage In Taiwan. Transportation Research Part E: Logistics and Transportation Review. 47(6): 822-836.

[37] Huang, C-L. \& Kung, F-H. 2011. Environmental Consciousness and Intellectual Capital Management: Evidence from Taiwan's Manufacturing Industry. Management Decision. 49(9): 1405-1425.

[38] Clemens, B. \& Bakstran, L. 2010. A Framework of Theoretical Lenses and Strategic Purposes to Describe Relationships Among Firm Environmental Strategy, Financial Performance, and Environmental Performance. Management Research Review. 33(4): 393-405.

[39] Giovanni, P.D. \& Vinzi, V.E. 2012. Covariance Versus ComponentBased Estimations of Performance in Green Supply Chain Management. International Journal of Production Economics. 135(2): 907-916.
[40] Peng, Y.S. \& Lin, S.S. 2008. Local Responsiveness Pressure, Subsidiary Resources, Green Management Adoption and Subsidiary's Performance: Evidence From Taiwanese Manufactures. Journal of Business Ethics. 199-212.

[41] Zhu, Q., Sarkis, J. \& Lai, K. 2008. Green Supply Chain Management Implications for "Closing The Loop". Transport Research Part E. 44: 118.

[42] Hussey, D. M. \& Eagan, P. D. 2007. Using Structural Equation Modeling to Test Environmental Performance in Small and Medium-Sized Manufacturers: Can SEM Help Smes? Journal of Cleaner Production. 15(4): 303-312.

[43] Carter, C. R. \& Rogers, D. S. 2007. A Framework of Sustainable Supply Chain Management: Towards New Theory. International Journal of Physical: Distribution \& Logistics Management. 38(5): 360-387.

[44] Hong, P., Kwon, H. B. \& Roh, J. J. 2009. Implementation of Strategic Green Orientation in Supply Chain: An Empirical Study on Manufacturing Firms. European Journal of Innovation Management 12(4): 512-532.

[45] Beamon, B.M. 1999. Designing the Green Supply Green. Logistics Information Management. 12(4): 332-342. 